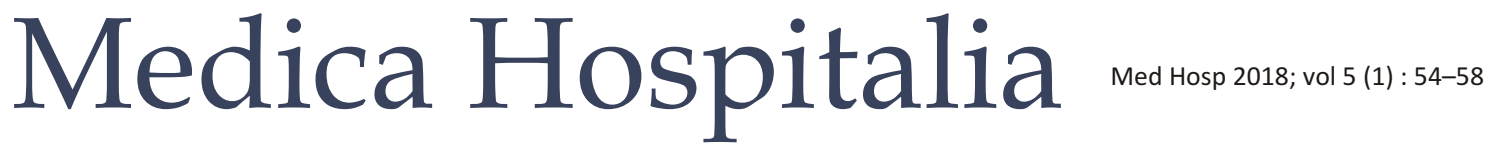

Case Report

\section{Seorang Anak Usia 6 Tahun dengan Penyakit Castleman : Kasus Jarang}

\author{
Dimas Tri Anantyo ${ }^{1}$, Fadhlan Rahman ${ }^{2}$ \\ ${ }^{1}$ Program Studi Pendidikan Dokter Bagian IImu Kesehatan Anak, Fakultas Kedokteran Universitas Diponegoro \\ ${ }^{2}$ Bagian Ilmu Kesehatan Anak, Fakultas Kedokteran Universitas Diponegoro
}

\begin{abstract}
Abstrak
Latar belakang : Castleman's Disease (CD) adalah penyakit limfoproliferatif yang dapat terjadi secara lokal ataupun sistemik. Penegakan diagnosis baku emas dari CD diperoleh dari pemeriksaan histopatologis biopsi jaringan kelenjar getah bening. Pengobatan definitive dari CD masih dalam tahap penelitian dan pengembangan. Tujuan dari laporan ini, adalah untuk melaporkan satu kasus yang terjadi di Semarang dan melakukan diskusi terkait dengan kasus tersebut sehingga penanganan yang tepat dapat dimulai sesegera mungkin.

Kasus : Seorang anak lelaki berusia 6 tahun datang ke rumah sakit dengan keluhan utama timbul massa di daerah inguinal dan submandibular yang berkembang perlahan tanpa gejala.

Diskusi : Setahun sebelum terdiagnosis CD anak dikeluhkan teraba benjolan di selangkangan anak, benjolan dirasa membesar lambat, nyeri tekan, terfiksir dan warna jaringan sama dengan sekitarnya, keluhan juga disertai dengan demam yang terjadi hilang timbul.

Simpulan : Pasien yang didiagnosis Castleman Disease (CD) pada April 2017 pada usia 6 tahun 3 bulan dengan massa di daerah inguinal dan submandibular yang berkembang perlahan tanpa gejala. Perawatan dari CD masih dalam penelitian.
\end{abstract}

Kata kunci : penyakit castleman, penyakit lymphoproliferative, massa lymph node

\section{A 6-year-old boy with castleman's disease : a rare case report}

\begin{abstract}
Background : Castleman's Disease (CD) is a lymphoproliferative disease that can occur locally or in general. Enforcement of a standard diagnosis of gold from a CD is obtained from histopathological features of lymph node tissue biopsy. Treatment from $C D$ is still in the research and development stage. Aim of this report, is to reports one case that occurred in Semarang and conducted a discussion related to the case so that the proper treatment can be initiated quickly.

Case : A 6-years-old boy came to the hospital with chief complaints of the mass in the inguinal and submandibular regions that develops slowly without symptoms.

Disscusion : A year before being diagnosed with a CD the child complained of being touched by a lump in the child's groin, a lump felt enlarged slowly, tender, fixed and the color of the tissue was the same as the surroundings, complaints were accompanied by fever, with temperature not measured, fever disappearing.

Conclusion : The patients diagnosed as a Castleman Disease (CD) sufferer in April 2017 at the age of 6 years 3 months with a mass in the inguinal and submandibular regions that develops slowly without symptoms. Treatment from CD is still in the research.
\end{abstract}

Keywords : castleman disease, lymphoproliferative disease, lymph node mass

\section{PENDAHULUAN}

Pada tahun 1954, Dr. Castleman pertama kali melaporkan pada 2 pasien yang memiliki pembesaran kelenjar getah bening mediastinum terlokalisasi yang ditandai dengan redundansi folikel limfoid dengan involusi pusat germinal dan proliferasi kapiler yang ditandai dengan hiperplasia endotel baik di daerah folikuler maupun interfolikuler. Kondisi tersebut, yang kini disebut
Castleman's Disease (CD), diketahui terkait dengan anemia hipokromik, hipergamaglobulinemia, dan plasmacytosis sumsum tulang, yang merupakan suatu fitur yang biasanya teratasi setelah reseksi bedah dari massa soliter yang terlibat dengan CD. Pada akhir 1960an dan awal 1970-an, deskriptor histologis yang sedang digunakan telah disempurnakan, yaitu dengan ditemukannya varian vaskular hialin, varian sel plasma, dan varian campuran. Pasien dengan varian sel plasma 
tercatat lebih rentan mengalami gejala B serta anemia dan hipergamaglobulinemia. ${ }^{1}$

Secara epidemiologi penyakit Castleman adalah entitas yang langka, termasuk varian diantaranya adalah penyakit Castleman Unicentric (UCD), Human Herpesvirus-8 plus penyakit Castleman (HHV-8 + MCD), dan Penyakit Castleman Multicentric Idiopatik (iMCD). UCD adalah yang paling umum dengan insidensi 16 per juta orang-tahun dan terjadi pada setiap usia. Insiden HHV-8 + MCD sangat bervariasi, sebagian besar mempengaruhi laki-laki yang HIV-positif. iMCD kemungkinan merupakan penyakit yang lebih heterogen dengan perkiraan insiden 5 per juta orang-tahun. ${ }^{1,6}$

Castleman's Disease (CD) adalah penyakit limfoproliferatif yang dapat terjadi secara lokal ataupun sistemik. Penegakan diagnosis baku emas dari CD diperoleh dari pemeriksaan histopatologis biopsi jaringan kelenjar getah bening. Pengobatan definitif dari CD masih dalam tahap penelitian dan pengembangan. Tujuan dari laporan ini, adalah untuk melaporkan satu kasus yang terjadi di Semarang dan melakukan diskusi terkait dengan kasus tersebut sehingga penanganan yang tepat dapat dimulai sesegera mungkin.

\section{LAPORAN KASUS}

Seorang anak laki-laki, didiagnosa sebagai penderita Castleman Disease (CD) pada bulan april 2017 pada usia 6 tahun 3 bulan dengan adanya massa pada regio inguinal dan submandibular yang berkembang secara lambat tanpa gejala. Setahun sebelum terdiagnosis CD anak dikeluhkan teraba benjolan di selangkangan anak, benjolan dirasa membesar lambat, nyeri tekan, terfiksir dan warna jaringan sama dengan sekitarnya, keluhan juga disertai dengan demam, dengan suhu tidak diukur, demam hilang timbul. Lalu anak diperiksakan ke RS
Banyumanik dan mendapatkan diagnosis Tuberkulosis (TB) ekstra paru kelenjar yang didapatkan dari skoring TB anak dengan skor 6, dan diobati sebagai TB klinis dengan Obat anti tuberkulosis (OAT) selama 6 bulan.

Setelah pengobatan pasien diperiksakan ke Balai Kesehatan Masyarakat (Balkesmas) dan tes tuberkulin dengan hasil negatif, namun benjolan bertambah jumlahnya. Setelah itu pasien diperiksakan ke Puskesmas Srondol dan dirujuk ke Rumah Sakit Nasional Diponegoro (RSND) dengan indikasi pembesaran kelenjar getah bening. Di RSND pasien di diagnosis sebagai limfadenopati multipel dan dirujuk ke Rumah Sakit Elisabeth untuk menjalani biopsi tumor. Setelah dilakukan biopsi massa dan dilakukan pemeriksaan histopatologi didapatkan gambaran folikel hiperplasia, onion-skin appearance, pembuluh darah yang mengalami hialinisasi dan gambaran lollipop, serta tidak ditemukan gambaran keganasan dengan kesimpulan sesuai gambaran castleman disease.

Pasien tidak menunjukkan keadaan klinis yang spesifik, seperti batuk pilek yang timbul dan hilang sendiri tanpa pengobatan, kelelahan dan demam hilang timbul tanpa penyebab yang jelas. Telah dilakukan pemeriksaan MRI pada pasien dengan hasil limfadenopati multiple regio colli dan inguinal.

Terapi yang diberikan kepada pasien terkait dengan diagnosa castleman disease adalah program pembedahan dengan cara eksisi kelenjar getah bening yang membesar di regio submandibular sinistra. Ukuran kelenjar getah bening yang dilakukan eksisi kurang lebih sekitar $12 \mathrm{~cm} \times 4 \mathrm{~cm} \times 2 \mathrm{~cm}$. Paska tindakan eksisi tidak dilakukan tindakan definitif lain seperti kemoterapi maupun radiasi terkait tatalaksana castleman disease karena belum adanya protokol spesifik tatalaksana castleman disease. Terapi lain yang diberikan hanya bersifat simptomatis untuk mengurangi gejala seperti

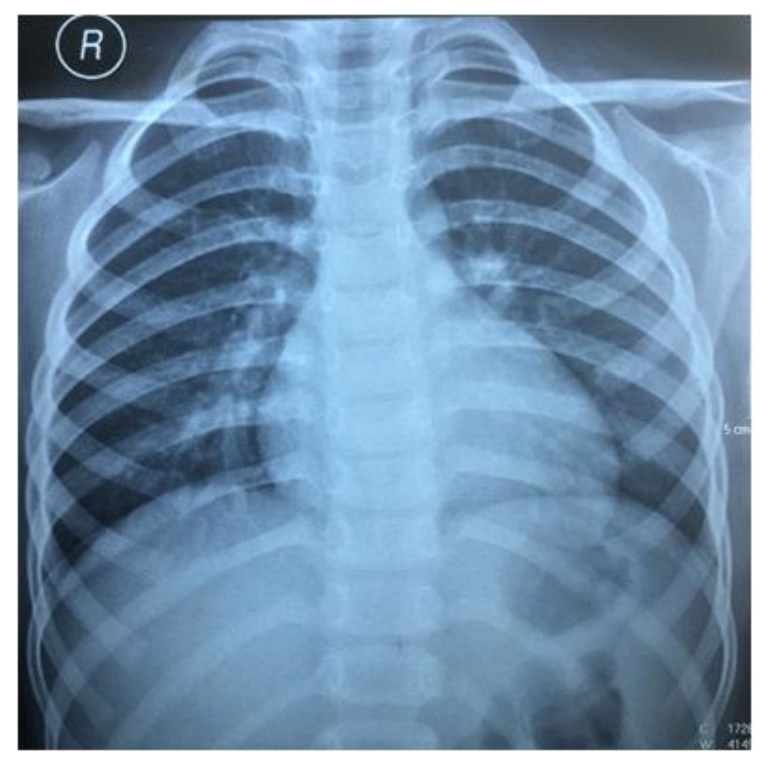

Gambar 1. Pemeriksaan X Foto Thorax sebelum terdiagnosis Castleman Diseases 


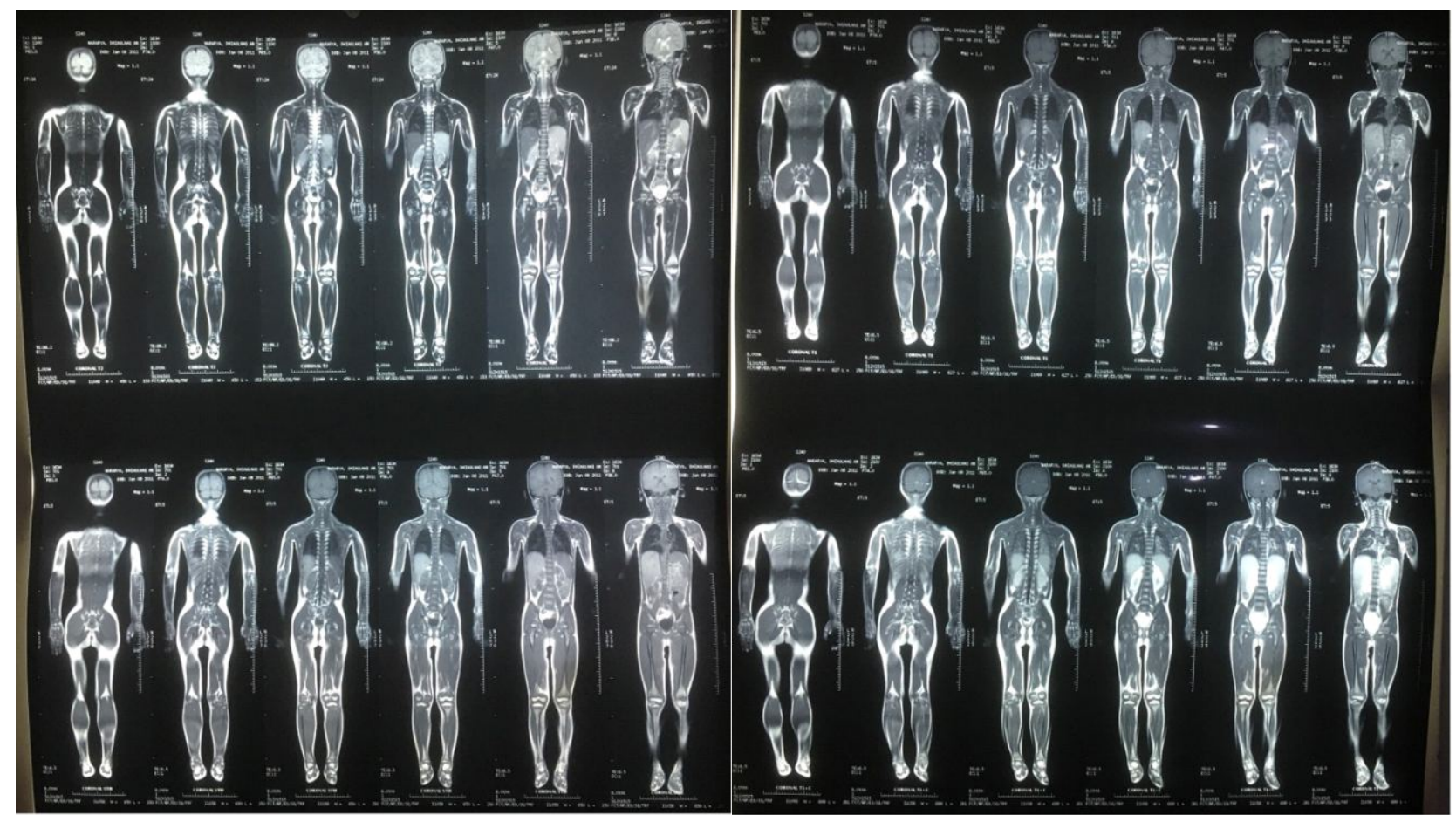

Gambar 2. Hasil MRI setelah terdiagnosis Castleman Diseases
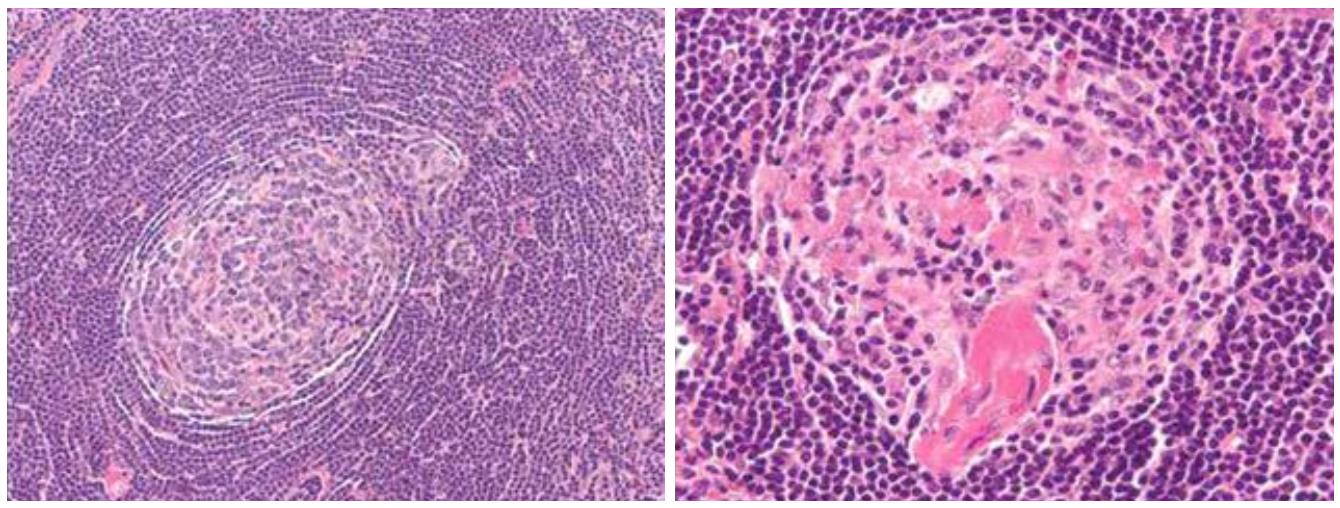

Gambar 3. Gambaran histopatologi Hyaline-vascular Castleman disease dengan pengecatan hematoksilin eosin (HE) (kiri perbesaran 40x, kanan 400x).

pemberian analgetik apabila pasien merasakan nyeri dan antipiretik apabila pasien mengeluhkan demam. Tiga bulan paska eksisi pasien mengeluhkan adanya sensasi nyeri dan pembesaran pada kelenjar getah bening submandibula dextra dan inguinal. Pemberian analgetik dan methyprednisolone oral dengan dosis $1 \mathrm{mg} /$ $\mathrm{kgBB} /$ hari selama 7 hari dapat mengurangi sensasi rasa nyeri dan pembesaran kelenjar getah bening submandibula dan inguinal pada pasien tersebut sementara waktu.

\section{DISKUSI}

Castleman Disease (CD) adalah penyakit yang penyebabnya belum diketahui, penyakit ini pertama kali ditemukan oleh Benjamin Castleman pada tahun 1956 dan sekarang diklasifikasikan menjadi dua subkelompok, yaitu lokal/unicentric (UCD) dimana hanya satu kelompok limfonodi pada satu area yang terlibat, dan tersebar/multicentric (MCD) dimana ada dua atau lebih kelompok limfonodi. Dan berdasarkan gambaran histopatologinya $\mathrm{CD}$ dibagi menjadi tiga subtipe, yaitu hyaline-vascular CD (HV-CD), plasma cell $\mathrm{CD}$ (PC-CD) dan plasmablastic varian yang berkaitan dengan infeksi HHV-8 dan HIV. ${ }^{1}$ (Level of Evidence 3A)

Mayoritas pasien dengan HV-CD tidak menunjukkan gejala klinis ataupun memiliki gejala terkait dengan efek dari massa terhadap sekelilingnya seperti pada massa mediastinal dapat ditemukan nyeri dada, batuk atau kesulitan bernafas, sedangkan jika 

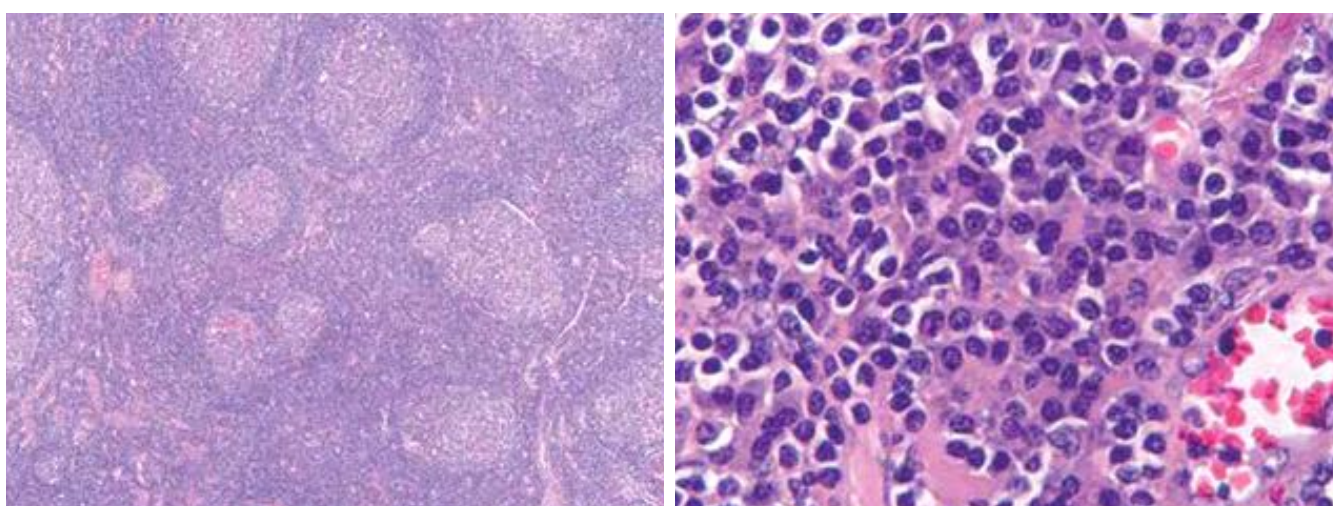

Gambar 4. Gambaran histopatologi Plasma cell Castleman Disease dengan pengecatan HE (kiri perbesaran 25x, kanan 400x).
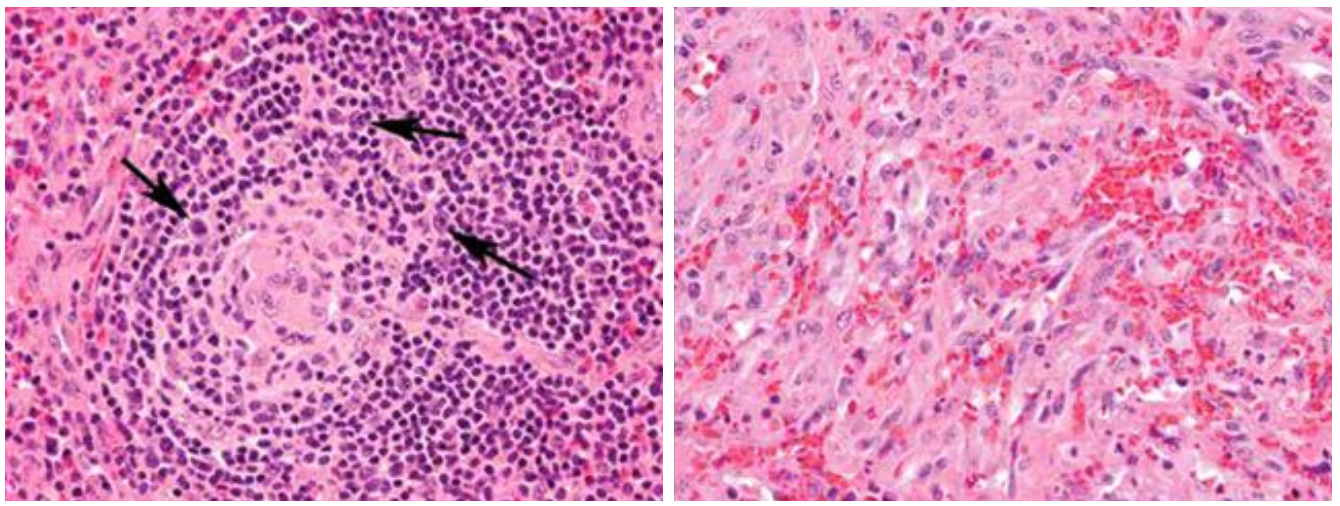

Gambar 5. Gambaran histopatologi Plasmablastic Castleman Disease varian yang berkaitan dengan infeksi HHV-8 dan HIV dengan pengecatan HE (kiri perbesaran 400x, kanan perbesaran 400x memperlihatkan adanya keterlibatan nodal dari Sarkoma Caposi).

massa terdapat di abdomen terkadang terdapat juga nyeri pada perut. Namun pada beberapa kasus, demam, keringat pada malam hari, dan berat badan yang sulit naik atau cenderung turun mungkin bisa ditemukan. Dikatakan bahwa respon sistemik tersebut kebanyakan berkaitan denganadanya sel plasma, namun pada HV-CD juga menunjukkan gejala-gejala tersebut. Gejala sistemik umum ditemukan pada MCD sesuai dengan meningkatnya kadar sitokin yang merupakan kunci dari timbulnya gejala. Demam, keringat pada malam hari, dan berat badan yang sulit naik, anemia, kelelahan, limfadenopati multipel dan hepatosplenomegali. Pada kasus yang berat juga dapat ditemukan kebocoran vaskular dimana pada pasien mungkin untuk didapati asites, efusi pleura atau edema perifer. MCD dapat ditemukan berkaitan dengan polineuropati, organomegali endokrinopati, protein monoklonal dan kelainan kulit atau disebut juga sindroma POEMS. ${ }^{3,4}$ (Level of Evidence 3A)

Diagnosis $\mathrm{CD}$ ditegakkan dari gambaran jaringan limfonodi yang terlibat, menunjukkan gambaran khas dari CD. Biopsi dengan melakukan eksisi jaringan merupakan baku emas untuk melakukan diagnosis CD, khususnya jika pasien diperkirakan memiliki UCD dapat berlaku juga sebagai eksisi terapeutik. Pengecatan immunohistokimia untuk Latency Associated Nuclear Antigen (LANA) atau PCR dapat digunakan untuk mendeteksi keberadaan HHV-8 di daerah limfonodi. ${ }^{3,5}$ (Level of Evidence 5)

Karena jarang ditemukannya kekambuhan dari CD lokal setelah reseksi dilakukan, pemebedahan eksisi total merupakan tatalaksana yang lebih dipilih untuk kasus ini dikarenakan prognosis tanpa kekambuhannya ditemukan hingga 20 tahun. Jika tidak dimungkinkan untuk dilakukan pembedahan, tindakan debulking harus dipertimbangkan khususnya jika terdapat gejala lokal ataupun risiko kompresi organ vital sekitar. Intensity-modulated radiation therapy (IMRT) dinyatakan sebagai pendekatan baru radioterapi untuk $C D$ yang sulit untuk dilakukan terapi pembedahan seperti di regio thoraks, dilaporkan bahwa dengan radioterapi beberapa pasien tidak menunjukkan gejala untuk waktu yang panjang, ataupun menggunakan kemoterapi demi mengurangi ukuran limfonodi hingga mencapai ukuran dimana selanjutnya dapat dilakukan. ${ }^{4}$ (Level of Evidence $3 A)$ 
Pada sedikit kasus yang dilaporkan, dilakukan terapi dengan menggunakan steroid, penggunaan glukokortikoid serta obat antiangiogenik seperti thalidomide memperbaiki gejala dan membantu koreksi kelainan laboratorium darah, namun efek yang diberikan bersifat sementara. Beberapa kasus yang lain melaporkan, pasien $\mathrm{CD}$ tanpa pengobatan apapun tidak menunjukkan gejala atau menunjukkan perbaikan bahkan remisi komplit. Lokasi limfadenopati tidak mempengaruhi hasil pengobatan. ${ }^{4}$ (Level of Evidence $3 \mathrm{~A}$ )

Terapi yang digunakan untuk MCD yaitu dengan menggunakan kemoterapi. Regimen kemoterapi untuk limfoma hodkins adalah regimen yang paling sering digunakan, yang juga digunakan pada pasien anak. Regimen kemoterapi lain yang lazim digunakan yaitu kombinasi siklofosfamid, doxorubicin, vincristine dan prednisolon (CHOP). Peran radioterapi pada MCD tidak menentu, dikarenakan adanya laporan dimana radioterapi dapat berguna sedangkan pada laporan lain tidak menunjukkan respon. Pada laporan kasus lain penggunaan steroid cukup untuk melakukan remisi walaupun terapi waktu terapi harus lebih lama. Penggunaan rituximab, antibodi monoklonal terhadap CD20 yang biasanya diproduksi oleh plasmablastic CD, menunjukkan aktivitas yang signifikan terhadap HIV positif MCD ketika digunakan sebagai monoterapi ataupun dikombinasikan dengan kemoterapi. ${ }^{2,3,4,5}$ (Level of Evidence 5)

Manifestasi klinis yang beragam mempersulit diagnosis dari CD. Ini adalah salah satu alasan dari angka kejadian dan prevalensi dari penyakit ini rendah. Maka dari itu penting untuk dilakukannya penelitian lebih lanjut mengenai $C D$ agar pasien bisa mendapatkan diagnosis dan terapi yang dini serta adekuat.

\section{SIMPULAN}

Seorang anak laki-laki, didiagnosa sebagai penderita Castleman Disease (CD) pada bulan april 2017 pada usia 6 tahun 3 bulan dengan adanya massa pada regio inguinal dan submandibular yang berkembang secara lambat tanpa gejala. Diagnosis CD ditegakkan dari gambaran jaringan limfonodi yang terlibat, menunjukkan gambaran khas dari CD. Manifestasi klinis yang beragam mempersulit diagnosis dari $\mathrm{CD}$. Ini adalah salah satu alasan dari angka kejadian dan prevalensi dari penyakit ini rendah.

Meskipun Castleman Disease merupakan kasus yang jarang dijumpai, penulis menyarankan sangat penting untuk sedini mungkin menegakkan diagnosis berdasarkan temuan simptom dan gejala yang ada. Agar selanjutnya terapi yang dapat diprogramkan bisa lebih efektif dan adekuat untuk meningkatkan kualitas hidup pasien agar dapat menjadi lebih baik.

\section{DAFTAR PUSTAKA}

1. Fetica, B., Pop, B., Lisencu, C., Rancea, A. C., Coman, A., Cucuianu, A., Petrov, L. Castleman disease. A report of six cases. Clujul Medical, 2014; 87(3), 192.

2. Soumerai, J. D., Sohani, A. R., Abramson, J. S. Diagnosis and management of Castleman disease. Cancer control, 2014;21(4), 266-278.

3. Cervantes, C. E., Correa, R. Castleman disease: A rare condition with endocrine manifestations. Cureus, 2015; 7(11).

4. Farruggia, P., Trizzino, A., Scibetta, N., Cecchetto, G., Guerrieri, P., D'Amore, E. S., D'Angelo, P. Castleman's disease in childhood: report of three cases and review of the literature. Italian journal of pediatrics, 2011;37(1), 50.

5. Chan, K. L., Lade, S., Prince, H. M., \& Harrison, S. J. Update and new approaches in the treatment of Castleman disease. Journal ofblood medicine, 2016;7,145.

6. Simpson D. Epidemiology of Castleman Disease. Hematol Oncol Clin North Am, 2018;32(2):1-10. 